\title{
СКРЫТНОСТЬ АНАЛИТИЧЕСКИХ ХАОТИЧЕСКИХ СИГНАЛОВ
}

\author{
П. Ю. КОСТЕНКО, В. В. СЛОБОДЯНЮК, А. Н. БАРСУКОВ
}

Харьковский университет Воздушных Сил, Украина, Харьков, 61023, ул. Сумская 77/79

\begin{abstract}
Аннотация. В статье рассмотрен подход к конструированию аналитических хаотических последовательностей, обладающих статистическими и динамическими характеристиками, близкими к характеристикам белого шума. Для этих последовательностей введено понятие скрытности и задана ее мера. Изучены аттракторы сконструированных последовательностей и их взаимные корреляционные функции. Результаты статьи могут быть использованы для повышения скрытности радиотехнических систем передачи информации.
\end{abstract}

Ключевые слова: хаотическая последовательность; аттрактор; аналитический хаотический сигнал; IID-скрытность; BDS-статистика

Одной из важных характеристик радиотехнических систем передачи информации (РТС ПИ), которые функционируют в условиях радиоэлектронного подавления (РЭП) и в условиях несанкционированного доступа (НСД) к информации, является их скрытность. Под скрытностью понимают способность РТС ПИ противостоять действию радиотехнической разведки $[1,2]$ с заданной вероятностью $P_{\mathrm{p}}$ средствами несанкционированного доступа. Тогда скрытность определяется значением вероятности $P_{\text {скр }}=1-P_{\mathrm{p}}$.

В свою очередь радиотехническая разведка предполагает последовательное решение трех основных задач с вероятностью $P_{\mathrm{p}}=P_{\text {обн }} P_{\text {стр }} P_{\text {инф }}:$ выявление факта работы РТС ПИ (обнаружение сигнала с вероятностью $\left.P_{\text {обн }}\right)$; определение структуры обнаруженного сигнала и его основных параметров с вероятностью $P_{\text {стр }}$, и раскрытие информации, содержащейся в сигнале с вероятностью $P_{\text {инф}}$. Сомножители в выражении $P_{\mathrm{p}}$ учитывают соответственно энергетическую, структурную и инфор- мационную скрытность сигнала, которая реализуется криптографическими методами.

Величина $P_{\text {обн }}$ определяет условную вероятность обнаружения сигнала в присутствии шума на входе приемника при условии, что этот сигнал действительно есть. Важно отметить, что обнаруженный процесс может быть, как искусственного происхождения, содержащий полезную информацию (сигнал), так и естественного происхождения (шум), который не представляет интереса для систем РЭП.

В большинстве случаев средства радиоразведки решают задачу обнаружения с использованием некогерентной обработки сигналов в энергетическом приемнике, независимо от их принадлежности к тому или иному классу.

Одним из путей решения проблемы обеспечения энергетической скрытности является использование широкополосных сигналов (ШПС). Большинство ШПС обладает достаточной энергетической скрытностью. В то же время структурную скрытность известных 


\section{БИБЛИОГРАФИЧЕСКИЙ СПИСОК}

1. Кувщинов О. В. Оцінка структурної скритності широкосмугових сигналів / О.В.Кувшинов, Р. М. Вознюк // Збірник наукових праць ВІТІ НТУУ «КПІ». - 2011. - № 1. - С. 106-111. - Режим доступа : http://viti.edu.ua/files/zbk/2011/14_1_2011.pdf.

2. Основы теории скрытности: учеб, пособие / 3. М. Каневский, В. П. Литвиненко, Г.В.Макаров, и др. - Воронеж : ВГУ, 2006. - 202 с.

3. Geza Kolumban, Tamas Krebesz, Chi Kong Tse and F.C.M. Lau, "Basics of Communications Using Chaos," Chaotic Signals in Digital Communications, Edited by Marcio Eisencraft, Romis Attux and Ricardo Suyama, CRC Press, 2013.

4. Куприянов А. И. Теоретические основы радиоэлектронной борьбы : учеб, пособие / А. И. Куприянов, А. В. Сахаров. - М.: Вузовская книга, 2007. $356 \mathrm{c}$.

5. Короновский A. A. О применении хаотической синхронизации для скрытой передачи информации / А. А. Короновский, О.И. Москаленко, А.Е.Храмов // Успехи физических наук. - 2009. - Т. 179, № 12, C. 281-1310. - DOI : $\underline{10.3367 / U F N r .0179 .200912 c .12}$ $\underline{81}$.

6. Скрытность передачи в системах связи с хаотическими сигналами / Н.В.Захарченко, С. М.Горохов, В. В. Корчинский, Б. К. Радзимовский // Вимірювальна та обчислювальна техніка в технологічних процессах. - 2013. - № 3. - С. 41-45. - Режим доступа : http://journals.khnu.km.ua/vottp/pdf/2013 3/32.pdf.

7. Непараметрический BDS-обнаружитель хаотических сигналов на фоне белого шума / П. Ю.Костен- ко, К. С. Васюта, С.Н. Симоненко, А. Н. Барсуков // Известия вузов. Радиоэлектроника. - 2011. - Т. 54, № 1. - C. 23-31. - Режим доступа : http://radio. kpi.ua/article/view/S0021347011010031.

8. Оценка структурной скрытности хаотических сигналов / П. Ю. Костенко, С. Н. Симоненко, А. Н. Барсуков, А. В. Антонов // Известия вузов. Радиоэлектроника. - 2012. - Т. 55, № 11. - С. 3-10. - Режим доступа : http://radio.kpi.ua/article/view/S00213470121 10015.

9. Фалькович C. Е. Основы статистической теории радиотехнических систем. Учеб. пособие / С.Е.Фалькович, П.Ю.Костенко. — Харьков : НАУ «ХАИ», 2005. - $390 \mathrm{c}$.

10. Динамические и статистические характеристики линейно-преобразованной хаотической последовательности / П.Ю.Костенко, К. С. Васюта, В. И. Сторожев, С.А.Олейник // Известия вузов. Радиоэлектроника. — 2006. — Т. 49, № 7. - С. 32-41. — Peжим доступа : http://radio.kpi.ua/article/view/S0021347 006070041

11. Костенко П. Ю. Повышение скрытности сигналов на основе усложнения аттрактора хаотического процесса с использованием линейного преобразования с ядром Мандельброта / П. Ю. Костенко, К. С. Васюта, С.Н.Симоненко // Известия вузов. Радиоэлектроника. - 2010. - Т. 53, № 12. - С. 14-23. - Режим доступа : http://radio.kpi.ua/article/view/S002134701012 $\underline{0022}$.

12. Использование BDS-статистики для оценки скрытности сигнала полученного перемешиванием хаотической несущей / П.Ю.Костенко, С. Н.Симоненко, А.Н.Барсуков, К.С. Васюта // Известия вузов. Радиоэлектроника. - 2010. - Т. 53, № 5. - С. 41-45. — Режим доступа : http://radio.kpi.ua/article/view/S002 1347010050055.

13. Корчинский В. В. Оценка структурной скрытности сигнальных конструкций на основе хаотических сигналов в системах передачи конфиденциальной информации / В.В.Корчинский // Наукові праці ОНАЗ ім. О. С. Попова. - 2012. - № 2. - С. 77-81. — Режим доступа : http://sbornik.onat.edu.ua/ua/metod/ download/350/ua.

14. Кипчатов A. A. Неограниченное возрастание размерности хаотических аттракторов при линейной фильтрации / А. А. Кипчатов, Е. Л. Козленко // Письма в ЖТФ. - 1997. - Т. 23, № 7. - С. 8-13. - Режим доступа : http://journals.ioffe.ru/articles/33436.

15. Кипчатов А. А. Реконструкция хаотических колебаний, прошедших через линейные фильтры / А. А. Кипчатов, Е. Л.Козленко // Письма в ЖТФ. 1999. - Т. 25, № 4. - С. 55-60. - Режим доступа : http://journals.ioffe.ru/articles/36317. 